\title{
OBITUARY: Brigadier Rupert Harding-Newman, MC
}

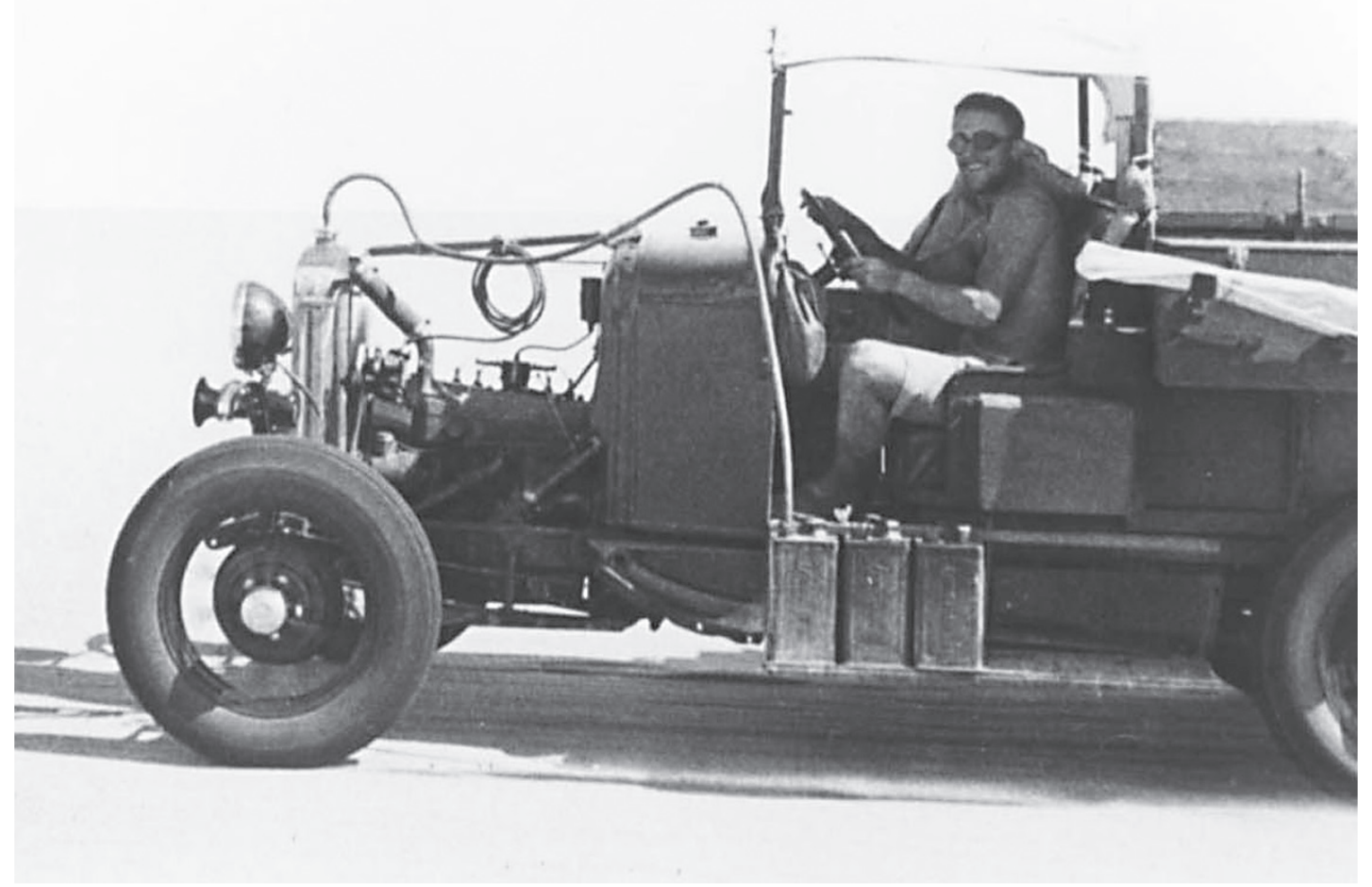

Rupert Harding-Newman in his modified Model A Ford car on the Selima-Terfawi sand sheet, 1932 (photo: Stephen Bagnold).

It is with great regret that I have to announce to the Society the death on 22 October 2007 of Brigadier Rupert Harding-Newman, MC, the last of that small band of explorers known as 'The Zerzura Club'. Founded in a Greek bar in Wadi Halfa in 1930, 'The Zerzura Club' was a loose grouping of individuals whose 'qualification for membership is to have taken part in hunting for the lost oasis of Zerzura or general exploration in the Libyan Desert'. Once a year, usually in the last week of June, those explorers who were in London for the annual meeting and dinner of the Royal Geographical Society (RGS) met and held their dinner (they plumped for the Café Royal). On the afternoon preceding the dinner they met at the RGS to compare notes on their recent travels in the Libyan Desert and showed photographs and cine-films to each other. The Zerzura Club was, in short, a gathering of Libyan Desert enthusiasts. They were mainly British military officers but they were joined by Italians (such as Colonel Lorenzini, 'the Lion of the Desert'), Hungarians (the most prominent of whom was the infamous 'Count' Almasy, of The English Patient fame), Germans (including Baron von der Esch) and Egyptians (mostly from the Egyptian Royal family, such as Prince Omar Toussoun). Whilst indulging their new 
craze for desert travel by motor car and aeroplane in the 1930s, these cosmopolitan adventurers were ostensibly searching the eastern tracts of the Libyan Desert for the lost oases and ancient cities of a vanished civilisation. In reality, however, they were mapping the desert for military reasons, marking vital wells and passable routes, as Britain, France and Fascist Italy struggled for dominion in Northeast Africa.

Although he was loathe to admit it in later years, Rupert Harding-Newman was caught up in this great power play when, as a young lieutenant in the Royal Tank Corps, he joined Ralph Bagnold's 1932 expedition across the Libyan Desert (for which Bagnold received the Founder's Medal of the RGS), being tasked with looking after the transport. Jabal 'Uweinat, at the centre of the Libyan Desert, was to be the main petrol and food dump for the journeys $1,900 \mathrm{~km}$ westwards into the disputed Sarra Triangle and 2,250 km southward to El Fasher, in the Anglo-Egyptian Sudan, where another dump was to be located. The 'Uweinat dump (in the event it proved more secure to have it at Jabal Kissu to the south) itself had to be built up by ferrying pre-positioned supplies on two $960 \mathrm{~km}$ double journeys from the Selima Oasis, across the vast Selima-Terfawi sand sheet. Bagnold knew that it would be hard to hit off the little oasis by dead reckoning. 'For comparison it was like starting from Newcastle on a compass bearing and trying to find a small garden somewhere in a vague rocky depression which was the size of London and the same distance away'. It was an odd sensation driving across this relentlessly flat and featureless sand sheet, the biggest then known (some $32,000 \mathrm{~km}^{2}$ ), for hour after hour, on a set course, with nothing to do but watch the thin shadow on the dial of the sun compass. The going was so smooth that the drivers lost all sense of motion and it was difficult to stay awake. At one point a driver actually fell asleep and his car veered off into the desert mirage, and Harding-Newman had to chase off after him. Eventually, they found Selima not by dead reckoning but by following the smell of the camels, which had brought the petrol to the oasis from Wadi Halfa. After loading up the modified Model A Ford cars Harding-Newman and company made the return journey to the Kissu dump in a day. They had passed to the north of one siting of Zerzura, but had found no signs of the existence of this lost oasis. Later, as they crossed the rocky country in the western part of the Sarra Triangle towards the Tibesti Mountains, it was Harding-Newman, along with his fellow 'tankie' Guy Prendergast, who saved the expedition from disaster, when they worked through the night to change over a cracked main engine-supporting bracket on one of the cars. During the last $320 \mathrm{~km}$ leg of their nearly $9,650 \mathrm{~km}$ journey the sorely-tried cars began to break up, with the main chassis frames cracking in the rear of two of them. Harding-Newman and Bagnold not only managed to repair them en route, but overhauled and sold them on to other users, including the ill-starred Lady Clayton-East-Clayton, who were involved in the exploration of the Libyan Desert and the hunt for Zerzura.

Early 1935 found Harding-Newman and his fellow Zerzura Club explorers Bill Kennedy Shaw, 'Count' Almasy and Baron von der Esch in the Kharga Oasis. Against a background of Italy's preparation for war with Abyssinia, and possibly Britain, Almasy and von der Esch planned a surveying expedition to the southeastern Libyan Desert. As Almasy later let slip, he was occupied during this expedition 'in writing-up all the important routes between the Darfur, 
the Fezzan and Egypt', which later proved of interest to the Italian military in both Rome and Libya at a time of great tension in Anglo-Italian relations. Meanwhile Harding-Newman and Kennedy Shaw prepared a similar expedition (and partly for the same purpose) with the big game hunter Colonel Strutt and his wife Mary, who had never been in the desert before. Back in September 1934 Almasy had asked to be allowed to join them. Knowing his reputation for taking unnecessary risks and his predatory homosexual habits, Kennedy Shaw wrote privately to Harding-Newman: 'I think not!' (They always referred to him with a Churchillian sneer as 'Almaasy' - with a long second vowel sound - much like Churchill's pronouncement of the Nazis as 'Naazis'). Shaw was also relieved that 'On-On Baggers' (Ralph Bagnold), who was ill, could not make it, since 'hush! Fortunately', this meant that the pace would be more 'relaxed' and 'there would be much more time to do things'.

Harding-Newman and Company had a hard and ultimately tragic journey from Kharga, through El-Aqaba (the Pass) in the Gilf Kebir (visiting part of Almasy's Zerzura, the Wadi Hamra, on the way), to 'Uweinat, and thence to Selima. After picking up petrol at the oasis they made a run of $145 \mathrm{~km}$ across the southern edge of the Selima sand sheet before turning southwestwards to strike the Grassy Valley. It was here in 1930, $160 \mathrm{~km}$ south of 'Uweinat, that Kennedy Shaw and Bagnold had seen 'a little green grass' in the bottom of a wide sandy valley and hoped that it might be Zerzura:

... but their surveys and the aneroid readings soon showed that were some hundreds of feet between the ground-level and the static water contour. As a site for Zerzura, Grassy Valley must be discounted. However our visit was not without profit for we found and excavated a solitary grave cairn which contained a skeleton buried in crouched position. Around its neck was a string of carnelian beads and by its side one pot. Both beads and pot are closely paralleled in the Egyptian Predynastic period.

Harding-Newman captured this discovery on cine-film. From Grassy Valley they continued across unexplored country to the Wadi Hawa (Valley of the Winds). 'It was near here...that Strutt met with an accident which ended so tragically. In a fall from a running board of a slow moving car he broke two ribs which pierced his lung'. They managed to get the big game hunter to Kutum, the headquarters of the Northern Darfur District. Despite a daring aerial rescue in a dust-storm by Guy Prendergast, Strutt died later in Khartoum.

There then occurred a memorable moment in the history of The Zerzura Club. The various explorers (who had carried their mess kit, or 'pansy garments', with them across the desert) were invited to dinner at the officers' mess of the Western Arab Corps at El Fasher by the commanding officer or Miralai, David Hunt, all candlelight and gleaming silver on starched white tablecloths, with Sudanese servants serving up the food and fine wines. At this dinner Almasy 'contradicted everything that anyone said about the Wadi Hawa, insisting that it provided the best, though not the most direct, route from the north to El Fasher. Eventually he rose up and seized pencil and paper, thrust these beneath Bill Shaw's nose and embellished it with a map illustrating his argument'. He and Kennedy Shaw also 'sat and argued about the position of a "lost oasis" [Bir Hamra]', north of Bir Bidi. Armed with information about the Western Arab Corps garrison at El Fasher, and convinced that the Wadi Hawa provided the best route to the capital 
of Darfur (both of interest to SIM, Italian Military Intelligence), Almasy returned to the north via Merga, Bir Bidi, to Selima and up to Kharga to rendezvous with von der Esch, who had been exploring and surveying the sites of archaeological interest in the Schallal area near Aswan and the Magarab near Wadi Halfa. All members of The Zerzura Club were aware that the destruction of the Aswan Dam in time of war by an Italian raiding party operating from 'Uweinat would have had a catastrophic effect on the predominantly agricultural Egyptian economy, with serious consequences for internal order and the British position in Egypt. Similarly they knew that the wrecking of the railway workshops, steamer ports and aerodromes at Aswan and Wadi Halfa would have prevented the rapid transfer of British troops between Egypt and the Sudan to face threats from Italian forces in Libya or East Africa.

Meanwhile Harding-Newman and Kennedy Shaw thoroughly explored the Wadi Hawa and looked for a more direct route from there to El Fasher, via the Malha Crater. After surveying a route, they struck north to Merga and Bir Bidi, where Kennedy Shaw took barometer readings and concluded that there could be no 'mystery well' between Merga and 'Uweinat, as Almasy believed. The party then progressed to Selima, unearthing on the way another perfectly preserved skeleton in the Wadi Prem, whom they named 'Potiphor Johnson', and whose skull they removed and took with them for scientific study. After loading up with more petrol, water and food at Selima they went west to 'Ain Doua well in the 'Uweinat. On April Fool's Day, as they ventured north, following the imposing western scarp of the Gilf Kebir, they ran into the worst sandstorm of the trip, as did Almasy and von der Esch, who were looking for signs of the lost army of King Cambyses in the Great Sand Sea. After this terrifying experience, Almasy reached the conclusion that the army had perished in just such a sandstorm. As his fellow member of The Zerzura Club, the Oxford geologist Dr Kenneth Sandford, put it: 'As Zerzura fades into the realm of legend once more, why should we not start a new search which might add historical interest to legitimate exploration? Why not start an aerial search for Cambyses' lost army. We have our Zerzura Club; why not a Cambyses Club?' It was to be another seventy years, however, before a group of archaeologists, mainly Egyptian, took him up on this suggestion. Despite their efforts to scan the sands for traces of bronze armour, the Great Sand Sea continues to refuse to yield its secret as to the exact fate of King Cambyses' army.

From Siwa, Almasy and von der Esch proceeded by relatively easy stages, following the tracks of Kennedy Shaw and Harding-Newman, along the desert route to Marsa Matruh, taking note of the Roman underground cisterns on the way. With the exception of the wells along the coast, these were the only natural source of water in the barren Western Desert. The valuable topographical information, maps and photographs accumulated by Almasy and von der Esch on their expedition later (in 1941) found their way into the official Nord Est Afrika handbook of the German Afrika Korps. It was Almasy's knowledge of 'the going' and the water sources in the Libyan Desert (the ostensible reason for the hunt for the lost rainwater oasis of Zerzura and the lost army of King Cambyses) which enabled him in May 1942 in 'Operation Salam' to run Rommel's spies to Cairo, evading the patrols of 'Bagnold's Boys', the Long Range Desert Group (LRDG). The latter had been set up in the summer of 1940 by General Wavell, at Bagnold's suggestion, to act as a diversionary force to bluff the large Italian forces in Libya into thinking 
that the British garrison in Egypt was greater than it was. Although the British Military Mission to the Egyptian Army would not let him go to join the LRDG, Harding-Newman provided much help to that unit on transport and intelligence. Following the capture of Kufra in March 1941 by General Leclerc's Free French forces operating from Chad, LRDG set up its advance base there, with Bagnold as military governor and Kennedy Shaw as garrison commander. Harding-Newman joined them there, on loan from the Military Mission, as a GSO 2. The autumn of 1941 found him at the main Eighth Army HQ at Ma'atten Baggush, where in the cool concrete dug-out among the sand-hills, with the paper screens carefully let down, for security reasons, over the maps on the walls, he told Bagnold and the latter's successor as CO of LRDG, Guy Prendergast, all they needed to know about their duties during the coming 'Crusader' offensive to relieve Tobruk. By this time the LRDG had become primarily a penetration and reconnaissance unit providing information on the movement of enemy forces (by means of the famous 'Road Watch') to verify tactical intelligence accumulated by the Eighth Army's 'Y' Service branch or the 'ULTRA' secret strategic intelligence derived from the interception, decryption and analysis by the Government Code and Cypher School at Bletchley Park of German Army and Air Force wireless messages encrypted on the Enigma machine.

Although Harding-Newman was Brigade Major of $22^{\text {nd }}$ Armoured Brigade during fierce fighting near Hagrag el Raml in early 1942, for which he received the Military Cross, he left Eighth Army in September, before the Second Battle of Alamein, in order to provide advice to the War Office in London on desert fighting. After serving as an instructor at Sandhurst, he commanded a training regiment of the Royal Armoured Corps. He remained 'with the tanks' after the war, commanding $8^{\text {th }}$ Royal Tank Regiment in Germany from 1950-52, and, as brigadier, the Royal Armoured Corps Centre at Bovington in 1958. Ever adventurous, he retired to the highlands of Scotland late in life, where this writer would often come across him, monkey wrench in hand, fixing various automobiles. Alert to the last, and remarkably young in mind and attitude towards the world, Harding-Newman remained readily accessible to a stream of writers, scholars, and TV producers, from a younger generation, who, their interest pricked by the novel and film The English Patient, were keen to find out about exploration, espionage and war in the Libyan Desert some seventy or more years ago. He was the last of a remarkable group of explorers who added considerably to our knowledge of the Libyan Desert. From a long-lived family, on his mother's side, he died some six weeks short of his centenary. He will always be remembered by later 'desert-wallahs' as 'young Rupert', being christened as such by his fellow explorer Mike Mason, in the latter's account of the 1935 expedition, Paradise of Fools.

Saul Kelly 